\title{
Correction to: The proliferation of multilateral development banks
}

\section{Miles Kellerman ${ }^{1}$}

Published online: 23 March 2018

(C) Springer Science+Business Media, LLC, part of Springer Nature 2018

\section{Correction to: Rev Int Organ (2018) \\ https://doi.org/10.1007/s11558-018-9302-y}

The original version of this article contained a typesetting mistake: Table 2 was incorrectly presented in the PDF.

The original article has been corrected.

The online version of the original article can be found at https://doi.org/10.1007/s11558-018-9302-y

Miles Kellerman

miles.kellerman@univ.ox.ac.uk

1 University of Oxford, Oxford, UK 